\title{
Pengaruh Penggunaan Lahan Dan Kinerja Lalu Lintas Terhadap Iklim Perkotaan Di Wilayah Peri-Urban Mamminasata
}

\section{The Effect of Land Use and Traffic Performance on Urban Climate in the Mamminasata Peri-Urban Area}

\author{
Sri Hidayat ${ }^{1}$, Syafri $^{2}$, Syahriar Tato $^{2}$ \\ ${ }^{1}$ Mahasiswa Program Studi Perencanaan Wilayah dan Kota Program Pascasarjana Universitas Bosowa \\ ${ }^{2}$ Program Studi Perencanaan Wilayah dan Kota Program Pascasarjana Universitas Bosowa \\ E-mail: hidayatblhd845@gmail.com
}

Diterima: 01 Februari 2021/Disetujui 12 Juni 2021

\begin{abstract}
Abstrak. Koridor ruas jalan Hertasning-Tun Abdul Razak merupakan wilayah peri-urban yang mengalami dinamika cukup tinggi akibat kebutuhan permukiman dan sarana kegiatan baru. Hal ini memicu terjadinya transformasi spasial. Transformasi spasial memberikan dampak pada peningkatan aktivitas antropogenik yang dapat mengubah iklim perkotaan. Peningkatan aktivitas antropogenik ditandai dengan perbedaan penggunaan lahan dan kinerja lalu lintas sepanjang koridor. Penelitian ini menggunakan metode kuantitatif untuk mengetahui hubungan variabel penggunaan lahan dan kinerja lalu lintas terhadap kondisi iklim perkotaan dengan analisis data menggunakan SEM PLS. Hasil pengujian hipotesis secara statistik terhadap pengaruh masing-masing variabel independen terhadap variabel dependennya menghasilkan kesimpulan penggunaan lahan berpengaruh signifikan terhadap kondisi iklim dimana nilai T-Statistik sebesar 2,752 > 1,96 atau nilai P sebesar 0,040 $<0,05$. Sementara kinerja lalu lintas tidak berpengaruh signifikan terhadap kondisi iklim perkotaan dengan nilai T-Statistik sebesar $1,071<1,96$ atau nilai P sebesar 0,285 > 0,05. Hasil ini juga menunjukkan bahwa penggunaan lahan di koridor ruas jalan Hertasning-Tun Abdul Razak dapat menyebabkan meningkatnya suhu perkotaan dikawasan tersebut. Namun peningkatan suhu perkotaan pada kawasan tersebut lebih disebabkan oleh aktivitas antropogenik pada penggunaan lahannya dan tidak dipengaruhi oleh luas area yang terbangun.
\end{abstract}

Kata Kunci: Penggunaan Lahan, Kinerja Lalu Lintas, Perubahan Iklim

\begin{abstract}
The corridor of the Hertasning-Tun Abdul Razak road section is a peri-urban area experiencing high dynamics due to the need for new housing and activity facilities. This triggers a spatial transformation. Spatial transformation has an impact on increasing anthropogenic activities that can change the urban climate. The increase in anthropogenic activity is indicated by differences in land use and traffic performance along the corridor. This study uses a quantitative method to determine the relationship between land use variables and traffic performance on urban climatic conditions with data analysis using SEM PLS. The results of statistical hypothesis testing on the effect of each independent variable on the dependent variable resulted in the conclusion that land use had a significant effect on climatic conditions where the Tstatistic value was 2.752> 1.96 or the P value was $0.040<0.05$. Meanwhile, traffic performance has no significant effect on urban climatic conditions with a T-statistic value of $1.071<1.96$ or a $P$ value of $0.285>0.05$. These results also indicate that land use in the Hertasning-Tun Abdul Razak road corridor can cause an increase in urban temperatures in the area. However, the increase in urban temperature in these areas is more due to anthropogenic activities in land use and is not influenced by the area that is built.
\end{abstract}

Keywords: Land Use, Traffic Performance, Climate Change

\section{Pendahuluan}

Perkembangan ruang di koridor ruas jalan Hertasning Tun Abdul Razak berkonstibusi terhadap perubahan pemanfaatan ruang, hal ini ditandai dengan berkembangnya beberapa fungsi-fungsi perkotaan yang diikuti pembangunan permukiman skala besar dan pembangunan fungsi-fungsi ekonomi komersil lainnya. Kondisi awal sebelum koridor Hertasning- Tun Abdul Razak dibangun di identifikasi merupakan lahan pertanian, namun saat ini telah menjadi lokasi bagi pemukim-pemukim baru dan pusat ekonomi baru (Sakti, 2016; Mokoginta et al., 2021 ). Dampak peruabahan iklim juga salah satunya menyebabkan bencana, diantaranya cucaca buruk, kebakaran lahan, dan tanah longsor akibat rekahan tanah (Sandi et al., 2020; Naser et al., 2021; Zahran et al., 2021) Berdasarkan konsep wilayah koridor yang dikemukan oleh McGee (1997) daerah sepanjang jalur transportasi akan mengalami transformasi spasial, ekonomi, sosial dan kultural yang pada akhirnya menyebabkan terjadinya transformasi wilayah yang sangat signifikan dari sifat kedesaan menjadi sifat kekotaan di sepanjang jalur transportasi darat (Yunus, 
2006). Dampak dari transformasi spasial pada wilayah periurban setidaknya akan memberikan dampak terhadap perubahan bentuk pemanfaatan lahan, harga lahan dan lingkungan abiotik (Yunus, 2008; Surya, 2020).

Salah satu indikator perubahan lingkungan abiotik adalah perubahan iklim perkotaan yang disebabkan peningkatan arus transportasi dan lahan terbangun. Semakin banyaknya lahan terbangun dan sedikitnya lahan terbuka untuk tumbuhnya vegetasi juga berpontensi untuk meningkatkan pemanasan global yang menyebabkan terciptanya iklim kota, yaitu iklim mikro yang berbeda dengan wilayah pinggirannya. Peningkatan suhu perkotaan salah satunya disebabkan oleh padatnya bangunan dan gedung-gedung yang tinggi, sehingga memantulkan cahaya matahari ke segala arah pada siang hari dan melepaskan kalor pada malam hari (Dahlan, dkk, 2011).

Konversi penggunaan lahan alami keartificial berdampak pada perubahan suhu, yaitu naiknya suhu harian. Peningkatan suhu permukaan bumi pada umumnya terjadi akibat perubahan perubahan tutupan lahan yang terjadi, berkurangnya area hijau akibat pembukaan lahan di perkotaan menyebabkan terjadinya efek urban heat island (Rushayati et al., 2016; Rasyidi et al., 2020; Buraerah et al, 2020). Beberapa efek negatif urban heat island diantaranya adalah gelombang panas di daerah perkotaan (Center for Disease Control, 1997), pengurangan kualitas udara dalam perkotaan akibat polusi dari panas berlebihan (Environmental Protection Agency, 2005), peningkatan pemakaian listrik sebesar 5-6\% (Environmental Protection Agency, 2005) dan akibat dari pemakaian listrik yang meningkat, mendukung penambahan penggunaan bahan bakar fosil yang menyebabkan timbulnya pemanasan global (UNEP, 2003). Penurunan tingkat layanan (level of service) jalan akibat meningkatnya volume lalu lintas dan peningkatan pencemaran udara dan suara serta volume limbah cair merupakan masalah yang kemudian muncul dan mempengaruhi tingkat kenyamanan hunian di Kawasan Pallangga.(MI Taking, 2015).

Penelitian sebelumnya menunjukkan adanya hubungan antara penggunaan lahan dengan kondisi iklim. Beberapa hasil penelitian dilakukan di kota Jakarta menunjukkan bahwa terdapat perbedaan suhu maksimum, dan dicapai perbedaan suhu minimum 1-3 ${ }^{\circ} \mathrm{C}$ antara Kota Jakarta (perkotaan) dan Bogor (pedesaan) (Maru \& Ahmad, 2015). Urbanisasi pada daerah perkotaan menyebabkan perubahan pola iklim. Hal ini berdampak pada profil suhu suatu wilayah, pola curah hujan, kelembapan relatif dan pola radiasi sinar matahari (Santamouris, 2013).

Penelitian yang dilakukan di Kota Indianapolis di Amerika Serikat tahun 2002 menunjukkan hasil iklim pada skala lingkungan mikro sangat dipengaruhi oleh peningkatan aktivitas perkotaan dan kepadatan kendaraan. Profil suhu pada daerah perkotaan sangat berbeda dengan pinggiran aglomerasi perkotaan. Pada daerah perkotaan cenderung lebih tinggi dibandingkan daerah pinggiran kota, hal ini dikarenakan permukaan didaerah perkotaan banyak menahan panas akibat penutupan lahan yang berupa jalan dan bangunan beton lainnya (Weng et al., 2004). Penelitian yang dilakukan oleh Rushayati, dkk, (2016) menunjukkan pengaruh yang signifikan dari perubahan penggunaan lahan terhadap temperatur permukaan kota Jakarta. Hampir seluruh wilayah Jakarta memiliki temperatur permukaan yang tinggi, namun beberapa wilayah yang memiliki RTH terindikasi memiliki temperatur permukaan yang lebih rendah. Dibandingkan dengan daerah terbangun, suhu permukaan RTH lebih rendah sekitar 3,2 0C.

Penelitian lainnya juga menjelaskan bahwa sektor transportasi memberikan pengaruh pada peningkatan kondisi iklim. Penelitian yang dilakukan oleh Huang, dkk, 2019 menunjukkan bahwa penggunaan bahan bakar bensin dan solar pada kendaraan berdampak global pada kualitas udara, kesehatan manusia, dan perubahan Penelitian ini merupakan penelitian lapangan (field research). Oleh karena itu pengumpulan data dilakukan melalui observasi, survei, eksperimental, dan dokumentasi dilapangan. iklim. Sektor transportasi berkontribusi utama pada peningkatan emisi gas rumah kaca yang dapat menyebabkan terjadinya perubahan iklim dalam skala makro.

Koridor ruas jalan Hertasning-Tun Abdul Razak sebagai kawasan yang mengalami peningkatan aktivitas antropogenik yang pesat, akan mengalami perubahan karakteristik iklim mikro perkotaan. Untuk itu penelitian ini mencoba untuk menganalisis hubungan penggunaan lahan dan kinerja lalu lintas terhadap iklim perkotaan. Sebagai bagian dari fenomena urban heat island. Hasil penelitian ini sekiranya dapat menjadi dasar perencanaan pembangunan wilayah pada koridor ruas jalan Hertasning-Tun Abdul Razak yang lebih berkelanjutan.

\section{Metode Penelitian}

Pendekatan penelitian ini menggunakan metode kuantitatif, dengan bentuk rumusan masalah asosiatif hubungan kausal. Penelitian ini merupakan riset kausal yang didasarkan pada analisis data primer. Riset kausal dengan eksperimen untuk mengetahui hubungan antara penggunaan lahan, kinerja lalu lintas, terhadap kondisi iklim.

Penelitian ini akan dilakukan pada koridor ruas jalan Hertasning yang berada pada wilayah administrasi Kota Makassar dan koridor ruas jalan Tun Abdul Razak di Kabupaten Gowa. Lokasi penelitian berada pada 4 administrasi Kecamatan yaitu di Kota Makassar terdiri atas Kecamatan Rappocini, Panakkukang, dan Kecamatan Manggala, sedangkan di Kabupaten Gowa berada pada Kecamatan Somba Opu. Lokasi pengambilan data dibagi atas 10 blok. Blok area lokasi penelitian seperti yang diperlihatkan pada gambar 4. Untuk area penggunaan lahan yang diteliti mencakup $200 \mathrm{~m}$ kiri dan kanan dari badan jalan. Untuk lokasi pemantauan kualitas udara dan kondisi iklim dilakukan pada pertengahan ruas jalan masing-masing blok.

Pemilihan lokasi didasarkan pada pertimbangan keterwakilan fenomena yang akan diteliti. Teknik sampling pada penelitian ini menggunakan teknik nonprobability sampling jenis sampling purposive. Di mana teknik penentuan lokasi sampling dengan pertimbangan tertentu seperti kebutuhan data yang diingin sesuai variabel dan kemudahan untuk melakukan pemantauan secara langsung dilapangan.

Pada penelitian ini terdapat 2 (dua) variabel yaitu variabel independen (bebas) dan variabel dependen (terikat). Variabel independent pada penelitian ini adalah 
penggunan lahan dan kinerja lalu lintas dan variabel dependen pada penelitian ini adalah kondisi iklim.

Tabel 1 Variabel Penelitian

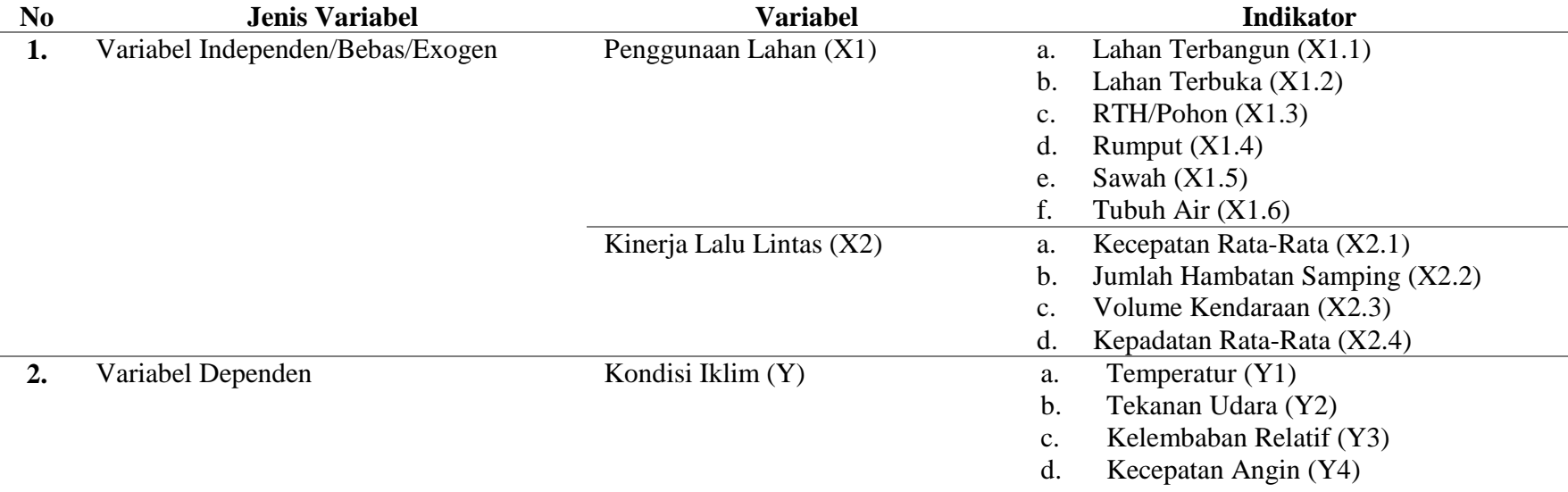

Adapun teknik pengumpulan data dilakukan secara langsung untuk data primer dan tidak langsung untuk data sekunder. Penentuan kondisi iklim dilakukan dengan pengambilan data meteorologi secara real time bersamaan dengan kualitas udara ambient. Data meteorologi diukur dengan peralatan Termometer untuk pengukuran temperatur udara, Barometer untuk tekanan udara, Higrometer untuk kelembaban relatif, Anemometer untuk kecepatan angin. Pengambilan data kinerja lalu lintas dilakukan dengan observasi, survei, dan dokumentasi langsung dilapangan.

Data kinerja lalu lintas yang ambil terdiri dari volume kendaraan, kecepatan rata-rata kendaraan, jumlah hambatan samping. Volume kendaraan ditentukan dengan menghitung volume kendaraan (Q) yang melewati suatu titik pengamatan. Pengamatan dilakukan merekam volume kendaraan yang melewati titik pengamatan dengan video recorder selama satu jam, kemudian hasil perekaman dilakukan perhitungan dengan counter tangan. Sementara untuk perhitungan kecepatan kendaraan (V) dilakukan dengan mengamati kecepatan yang dibutuhkan untuk menyelesaikan perjalanan antara dua tempat dalam satu ruas jalan yang akan diteliti dengan menggunakan GPS Garmin GPSMAP® 63sc Handheld. Untuk kerapatan (D) kendaraan dalam ruas jalan yang akan diteliti didapatkan dari perhitungan antara volume kendaraan (Q) dibagi dengan kecepatan kendaraan (V). Selain itu juga dilakukan pengumpulan data jumlah hambatan yang dilakukan dengan survei langsung dengan bantuan alat counter tangan. Data penggunaan lahan pada lokasi penelitian diambil dari data sekunder berupa hasil interpretasi citra satelit pleiades yang dieksekusi pada tahun 2019 dan telah dilakukan koreksi geometrik dan radiometrik, serta telah dicroping sesuai dengan lokasi pemantauan. Data original Citra Satelit Pleiades berupa data Citra Satelit Pleiades warna natural (3 Band - R, G, B) dengan resolusi spasial $50 \mathrm{~cm}$ yang merupakan hasil fusi antara data Citra Satelit Pleiades dalam moda multispektral dengan data Citra Satelit Pleiades dalam moda pankromatik atau berupa data Citra Satelit Pleiades bundle 4 Band (R, G, B, dan NIR).
Penelitian ini menggunakan metode analisis data dengan menggunakan software SmartPLS versi 3,0 yang dijalankan dengan komputer. PLS (Partial Least Square) merupakan analisis persamaan struktural (SEM) berbasis varian yang secara simultan dapat melakukan pengujian model pengukuran sekaligus pengujian model struktural. Model pengukuran digunakan untuk uji validitas dan reabilitas, sedangkan model struktural digunakan untuk menguji kausalitas (pengujian hipotesis dengan model prediksi). Menurut Ghozali (2006), PLS adalah metode analisis yang bersifat soft modeling karena tidak mengasumsikan data harus dengan pengukuran skala tertentu, yaitu berarti jumlah sampel dapat kecil (dibawah 100 sampel). Berdasarkan pada pertimbangan tersebut pada penelitian ini digunakan metode SEM PLS, dimana jumlah sampel yang tersedia untuk setiap indikator hanya 10 . Selain itu data pada penelitian ini, antara satu variabel dengan variabel yang lain memiliki skala yang berbeda.

Melalui metode SEM PLS, penelitian ini menggabungkan dua analisis statistik (regresi dan faktor), yaitu analisis faktor yang diakomodasi dalam model pengukuran dan analisis regresi dalam model struktural. Hal ini dimaksudkan untuk menguji hubungan antarvariabel dan mengembangkan instrumen pengukuran yang baik (Haryono dan Wardoyo, 2012). Berdasarkan dua maksud diatas analisis PLS pada penelitian ini terbagi dalam 2 tahapan utama yaitu pengukuran indikator atau variabel manifest (outer model) dan pengujian model struktural (inner model).

\section{Hasil dan Pembahasan}

\subsection{Analisis Penggunaan Lahan}

Salah satu variabel independen pada penelitian ini adalah pengunaan lahan. Perubahan penggunaan lahan merupakan dampak dari terjadinya urbanisasi di kawasan perkotaan. Fenomena ini juga terjadi pada kawasan ruas jalan koridor Hertasning dan Tun Abdul Razak. Namun pada kawasan ini lebih disebabkan keberadaan koridor jalan yang sangat strategis. Adapun hasil analisis penggunaan lahan pada kawasan ruas jalan koridor 
Hertasning dan Tun Abdul Razak diperlihatkan pada tabel dibawah ini :

Tabel 2 hasil Interpretasi Penggunaan Lahan

\begin{tabular}{|c|c|c|c|c|c|c|c|c|}
\hline \multirow[b]{2}{*}{ No } & \multirow[b]{2}{*}{ Blok Pemantauan } & \multicolumn{6}{|c|}{ Luas Penggunaan Lahan (Ha) } & \multirow[b]{2}{*}{$\begin{array}{l}\text { Luas } \\
\text { Total }\end{array}$} \\
\hline & & $\begin{array}{c}\text { Lahan } \\
\text { Terbangun }\end{array}$ & $\begin{array}{c}\text { Lahan } \\
\text { Terbuka }\end{array}$ & Pohon & Rumput & Sawah & $\begin{array}{c}\text { Tubuh } \\
\text { Air }\end{array}$ & \\
\hline 1 & Blok 1 & 32,1 & 0,9 & 6,2 & 5,7 & - & - & 45,0 \\
\hline 2 & Blok 2 & 38,3 & - & 6,5 & 0,1 & - & - & 44,9 \\
\hline 3 & Blok 3 & 40,2 & 0,2 & 3,9 & 0,8 & - & - & 45,0 \\
\hline 4 & Blok 4 & 32,9 & 1,2 & 3,5 & 6,5 & - & 0,7 & 44,9 \\
\hline 5 & Blok 5 & 28,2 & 0,7 & 2,8 & 12,9 & - & 0,4 & 45,0 \\
\hline 6 & Blok 6 & 12,8 & - & 4,2 & 19,2 & 4,2 & 4,5 & 44,9 \\
\hline 7 & Blok 7 & 22,0 & 0,4 & 3,7 & 15,1 & - & 4,0 & 45,0 \\
\hline 8 & Blok 8 & 8,4 & 10,5 & 4,4 & 6,3 & 14,1 & 1,3 & 45,0 \\
\hline 9 & Blok 9 & 14,0 & 1,9 & 6,1 & 9,5 & 13,1 & 0,4 & 45,0 \\
\hline 10 & Blok 10 & 12,5 & 1,5 & 6,0 & 13,8 & 9,7 & 1,6 & 45,0 \\
\hline
\end{tabular}

Berdasarkan data pada Tabel 2 diatas, luas penggunaan lahan terbangun semakin berkurang dari blok 1 sampai dengan blok 10. Untuk luas area terbangun terkecil terdapat pada blok 8 , hal ini dikarenakan pada blok 8 ini umumnya penggunaan lahannya berupa sawah. Sementara untuk luas lahan terbangun terbesar terdapat pada blok 4, hal ini karenakan pada blok ini terdapat pertemuan antara kegiatan perkantoran, jasa dan perdagangan. Adapun untuk penggunaan lahan seperti lahan terbuka, sawah dan tubuh air cenderung semakin luas dari blok 1 sampai dengan blok 10, hal ini dikarenakan lahan mulai dari blok 6 sampai dengan 10 belum sepenuhnya terbangun, masih terdapat penggunaan lahan berupa sawah seperti sebelum adanya koridor jalan koridor Hertasning dan Tun Abdul Razak. Sementara penggunaan lahan berupa pohon terlihat tidak banyak berubah dari blok 1 sampai dengan blok 10. Grafik kecenderungan luasan masing-masing pengunaan lahan untuk setiap blok diperlihatkan pada gambar dibawah ini.

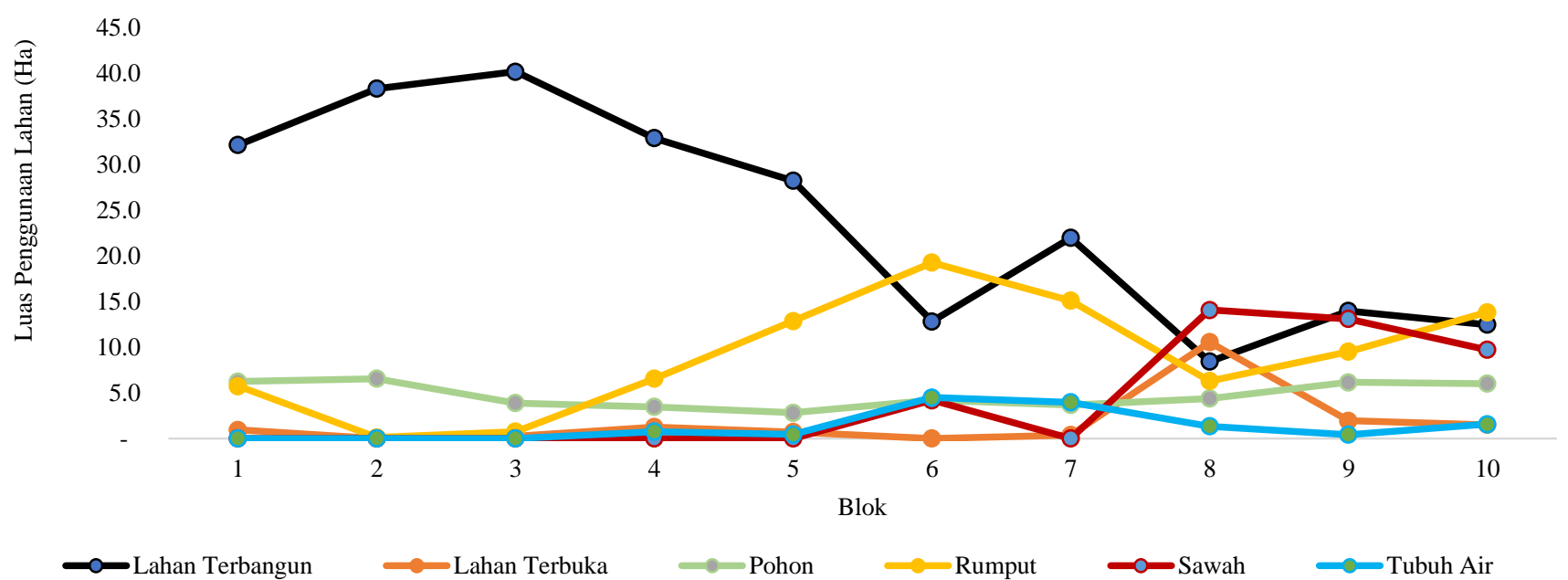

Gambar 1 Luas Penggunaan Lahan Untuk Setiap Blok

Hasil analisis penggunaan lahan ini semakin menegaskan bahwa telah terjadi urban sprawl pada koridor jalan koridor Hertasning dan Tun Abdul Razak. Hal ini sejalan dengan konsep wilayah koridor yang dikemukan oleh McGee (1997) dimana daerah sepanjang jalur transportasi akan mengalami transformasi spasial, ekonomi, sosial dan kultural yang pada akhirnya menyebabkan terjadinya transformasi wilayah yang sangat signifikan dari sifat kedesaan menjadi sifat kekotaan di sepanjang jalur transportasi darat (Yunus, 2006).

\subsection{Analisis Kinerja Lalu Lintas}

Variabel indenpenden lainnya dalam penelitian ini adalah kinerja lalu lintas. Kinerja lalu lintas menjadi variabel penting pada penelitian di ruas jalan koridor Hertasning dan Tun Abdul Razak, mengingat peningkatan aktivitas perdagangan dan jasa di ruas jalan ini menghasilkan tarikan mobilisasi penduduk skala besar yang menyebabkan tingkat pelayanan pada ruas jalan ini berada pada kategori E, dimana menunjukkan volume lalu lintas sudah mendekati kapasitas ruas jalan (Rahman, dkk, 2016). Berdasarkan MKJI (1997) fungsi utama dari suatu jalan adalah memberikan pelayanan transportasi sehingga pemakai jalan dapat berkendaraan dengan aman dan nyaman. Parameter arus lalu lintas yang merupakan faktor penting dalam perencanaan lalu lintas adalah volume, kecepatan, dan kerapatan lalu lintas. Untuk itu indikator yang digunakan pada variabel ini antara lain kecepatan, volume, kepadatan kendaraan, dan jumlah hambatan samping. Adapun hasil analisis kinerja lalu lintas ruas jalan koridor Hertasning dan Tun Abdul Razak diperlihatkan pada Tabel 3 dibawah ini : 

Tabel 3. Hasil Analisis Kinerja Lalu Lintas

\begin{tabular}{|c|c|c|c|c|c|}
\hline \multirow[b]{2}{*}{ No } & \multirow[b]{2}{*}{ Blok Pemantauan } & \multicolumn{4}{|c|}{ Indikator Kinerja Lalu Lintas } \\
\hline & & $\begin{array}{l}\text { Kecepatan Rata- } \\
\text { Rata }(\mathbf{K m} / \mathbf{J a m})\end{array}$ & $\begin{array}{c}\text { Jumlah Hambatan } \\
\text { Samping }\end{array}$ & $\begin{array}{l}\text { Jumlah Kendaraan } \\
\text { (Kendaraan) }\end{array}$ & $\begin{array}{l}\text { Kepadatan Rata-Rata } \\
\text { (Kendaraan Jam/Km) }\end{array}$ \\
\hline 1 & Blok 1 & 30,665 & 17 & 6799 & 111,31 \\
\hline 2 & Blok 2 & 27,6 & 28 & 4876 & 88,32 \\
\hline 3 & Blok 3 & 24,925 & 68 & 5130 & 103,07 \\
\hline 4 & Blok 4 & 28,7 & 40 & 6353 & 110,94 \\
\hline 5 & Blok 5 & 27,85 & 39 & 5213 & 93,61 \\
\hline 6 & Blok 6 & 35,975 & 20 & 4742 & 65,90 \\
\hline 7 & Blok 7 & 30,175 & 18 & 3498 & 58,29 \\
\hline 8 & Blok 8 & 31,775 & 15 & 2288 & 36,06 \\
\hline 9 & Blok 9 & 37,775 & 9 & 1848 & 24,49 \\
\hline 10 & Blok 10 & 38,1 & 8 & 1751 & 23,10 \\
\hline
\end{tabular}

Berdasarkan Tabel 3 diatas jumlah kendaraan dari blok 1 sampai dengan blok 10 cenderung mengalami penurunan. Jumlah kendaraan terbanyak terdapat pada blok 1 yaitu sekitar 6.799 kendaraan/Jam dan blok 4 sebesar 6.353 kendaraan/jam. Sementara jumlah kendaraan perjamnya yang paling sedikit terdapat pada blok 10 yaitu 1.751 kendaraan/jam. Hal ini menunjukkan tarikan dan bangkitan pada ruas jalan koridor Hertasning dan Tun Abdul Razak cenderung menurun dari jalan Hertasning ke jalan Tun Abdul Razak. Hal ini dapat dipahami dikarenakan pusat kegiatan perkantoran, perdagangan dana jasa dominan terdapat pada jalan Hertasning khususnya pada blok 1 sampai dengan 4.

Adapun untuk kecepatan rata-rata dari blok 1 sampai dengan blok 10 cenderung mengalami peningkatan, meski tidak signifikan. Sementara untuk kecepatan rata-rata hasilnya berbanding terbalik dengan kepadatan kendaraan dan banyaknya hambatan samping. Dimana kepadatan kendaraan dan banyaknya hambatan samping cenderung menurun dari blok 1 sampai dengan blok 10. Hal ini menunjukkan bahwa tingkat pelayanan jalan koridor Hertasning dan Tun Abdul Razak cenderung membaik dari blok 1 sampai dengan blok 10. Keadaan ini dapat dipahami dikarenakan kegiatan perkantoran, perdagangan dana jasa cenderung berkurang pada blok 6 sampai dengan 10 .

\subsection{Analisis Kondisi Iklim}

Variabel mediator pada penelitian ini adalah kondisi iklim. Hal ini didasarkan pada pertimbangan bahwa iklim mikro perkotaan sangat dipengaruhi oleh kondisi fisik dan aktivitas yang terjadi pada daerah perkotaan. Untuk itu pada penelitian ini dilakukan pengukuran kondisi iklim yang didasarkan pada indikator temperatur, tekanan, kelembaban relatif, dan kecepatan angin. Adapun hasil pengukuran kondisi iklim pada setiap blok lokasi pemantauan diperlihatkan pada tabel dibawah ini.

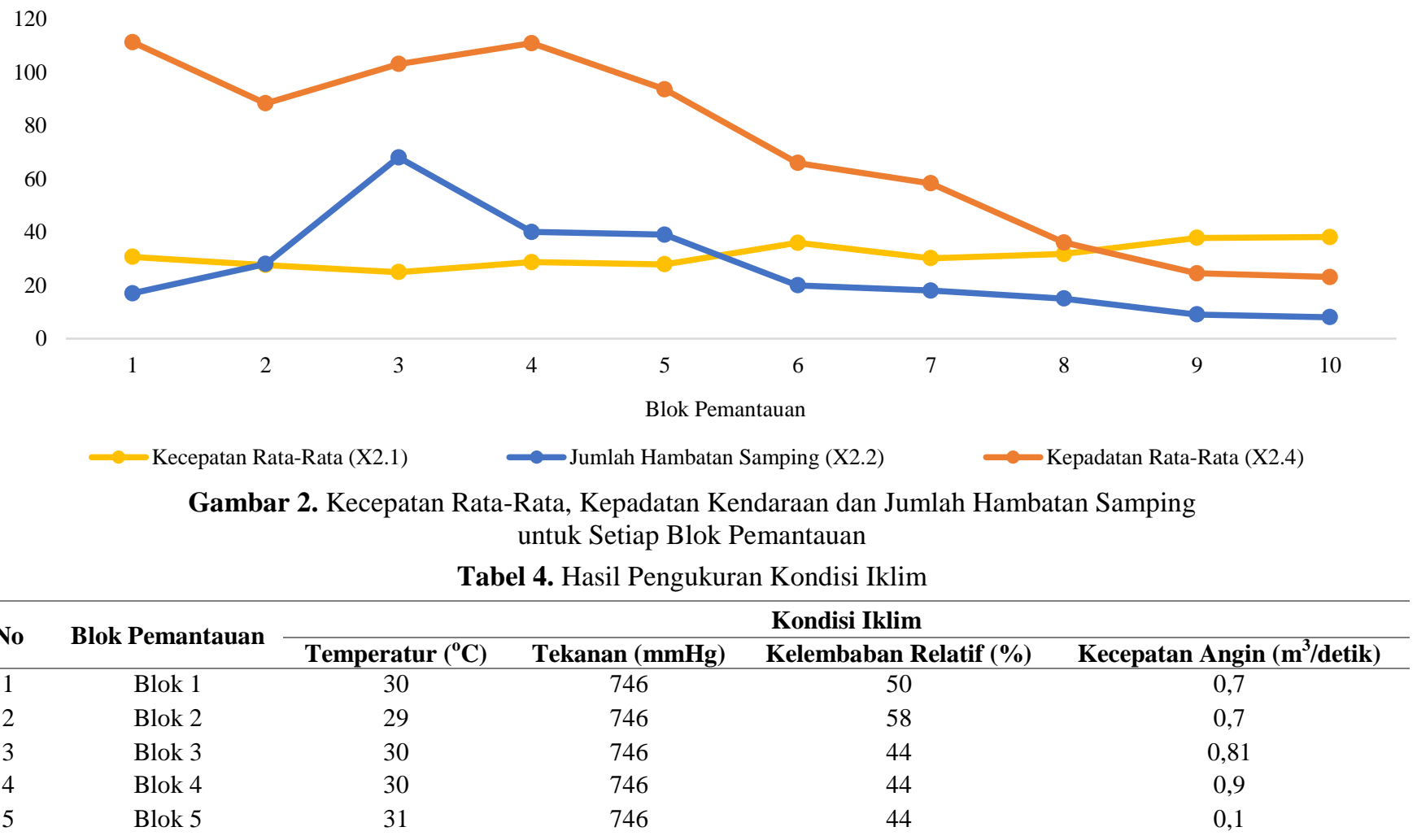




\begin{tabular}{cccccc}
\hline 6 & Blok 6 & 31 & 746 & 45 & 0,8 \\
7 & Blok 7 & 31 & 746 & 46 & 1 \\
8 & Blok 8 & 31 & 746 & 44 & 1 \\
9 & Blok 9 & 31 & 746 & 47 & 0,9 \\
10 & Blok 10 & 31 & 746 & 45 & 0,9 \\
\hline
\end{tabular}

Berdasarkan Tabel 4 diatas temperatur udara pada blok 5 sampai dengan 10 lebih tinggi 1 atau 2 derajat dibandingkan blok 1 sampai dengan 4 . Hal ini berbanding terbalik dengan kelembaban relatif dimana kelembaban cenderung menurun dari blok 1 sampai dengan blok 10. Hal ini dapat dipahami dikarenakan pada blok 5 sampai dengan 10 cenderung lingkungannya lebih terbuka sehingga intensitas penyinaran matahari lebih besar. Hal ini juga disebabkan faktor penutupan pohonnya pada blok 5 sampai dengan blok 10 tersebut cenderung lebih sedikit dibandingkan pada blok 1 sampai dengan 4. Adapun kondisi tekanan udara cenderung sama untuk semua blok lokasi pemantauan yaitu pada $746 \mathrm{mmHg}$. Sementara kecepatan angin untuk setiap blok bervariasi antara satu blok dengan blok lainnya. Dimana kecepatan angin terendah terdapat pada blok 1 dan 2 yaitu $0,7 \mathrm{mmHg}$ dan kecepatan angin tertinggi terdapat pada blok 4, 9 dan 10. Hal ini dapat dipahami dikarenakan pada blok 1 dan 2 umumnya terdapat banyak bangunan dan pohon maka pergerakan angin banyak terhalangi sehingga pada akhirnya kecepatan angin menjadi rendah, sedangkan pada blok 9 dan 10 kondisi lingkungan sekitarnya lebih terbuka, maka pergerakan angin lebih bebas sehingga kecepatan angin tinggi. Adapun gambaran hubungan indikator iklim tersebut dengan blok lokasi pemantauan diperlihatkan pada tabel dibawah ini.

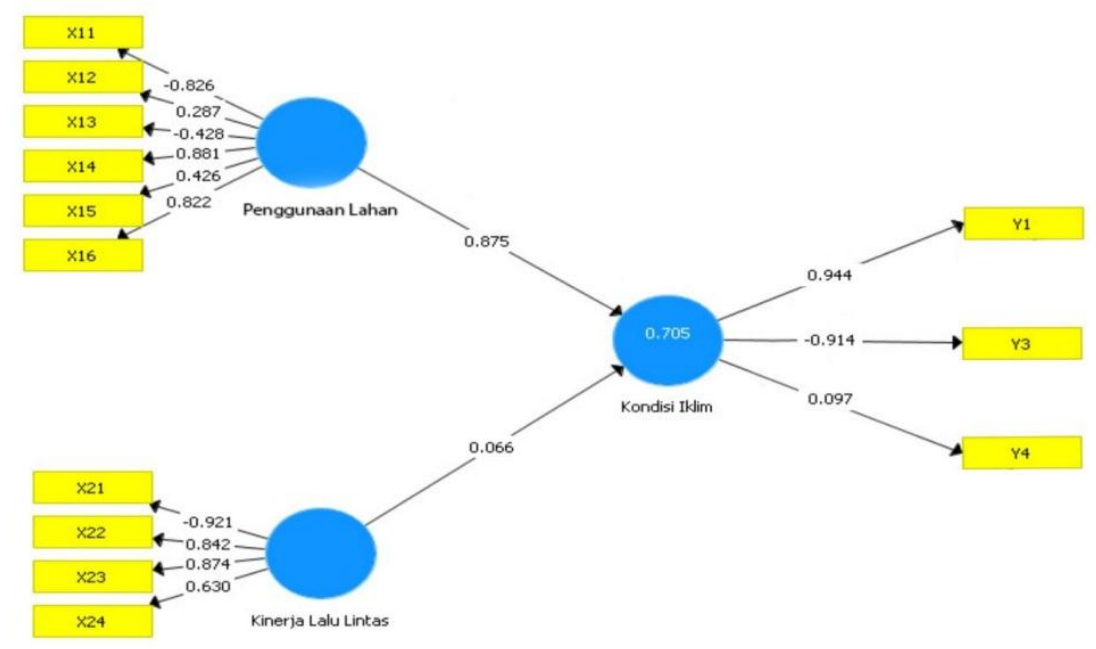

Gambar 3. Pengukuran Kondisi Iklim untuk Setiap Blok Pemantauan

\subsection{Hasil Evaluasi Model Struktural}

Evaluasi model struktural pada penelitian ini dikenal sebagai uji outer model. Outer model merupakan model yang menspesifikasi hubungan antara variable laten dengan indikator-indikatornya atau bisa dikatakan bahwa outer model mendefinisikan bagaimana setiap indikator berhubungan dengan variable latennya. Outer model diinterpretasikan dengan melihat nilai konvergen (konvergent validity). Model PLS Algorithm disajikan pada gambar di bawah ini.

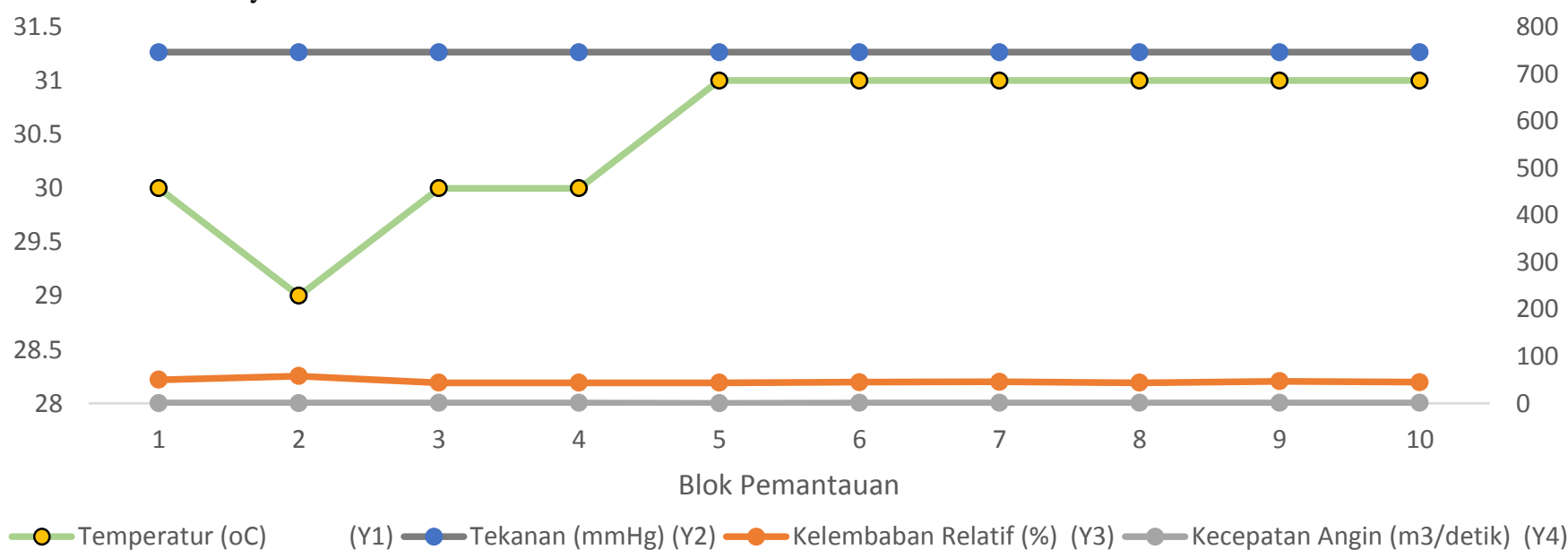

Gambar 4. Model PLS Algoritma 1 
Validitas konvergen yaitu mengukur besarnya Loading Factor untuk masing-masing variabel laten (indikator). Loading factor diatas 0,70 sangat direkomendasikan, namun demikian loading factor diatas 0,50 masih dapat ditolerir sepanjang model masih dalam tahap pengembangan. Hasil nilai loading factor untuk setiap indikator selengkapnya diperlihatkan pada tabel di bawah ini.

Tabel 5. Nilai Loading Factor Indikator Algoritma 1

\begin{tabular}{cccc}
\hline & $\begin{array}{c}\text { Kinerja Lalu } \\
\text { Lintas }\end{array}$ & $\begin{array}{c}\text { Kondisi } \\
\text { Iklim }\end{array}$ & $\begin{array}{c}\text { Penggunaan } \\
\text { Lahan }\end{array}$ \\
\hline X1.1 & & & $-0,826$ \\
X1.2 & & & 0,287 \\
X1.3 & & & $-0,428$ \\
X1.4 & & & 0,881 \\
X1.5 & & & 0,426 \\
X1.6 & & & 0,822 \\
X2.1 & $-0,921$ & & \\
X2.2 & 0,842 & & \\
X2.3 & 0,874 & & \\
X2.4 & 0,630 & 0,944 & \\
Y1 & & $-0,914$ & \\
Y3 & & &
\end{tabular}

\begin{tabular}{|c|c|c|c|}
\hline & $\begin{array}{l}\text { Kinerja Lalu } \\
\text { Lintas }\end{array}$ & $\begin{array}{l}\text { Kondisi } \\
\text { Iklim }\end{array}$ & $\begin{array}{c}\text { Penggunaan } \\
\text { Lahan }\end{array}$ \\
\hline Y4 & & 0,097 & \\
\hline
\end{tabular}

Pada tabel 5 di atas menunjukkan bahwa konstruk penggunaan lahan, nilai loading pada indikator X1.1 sebesar -0,826; X1.2 0,287, X1.3 -0,428, X1.4 0,881, X1.5 0,426 dan X1.6 sebesar 0,822. Konstruk Kinerja Lalu lintas, nilai pada indikator X2.1 sebesar -0,921, X2.2 0,842, X2.3 0,874 dan X2.4 sebesar 0,630. Konstruk Kondisi Iklim, nilai loading pada indikator Y1 sebesar 0,944, Y3 0,914 dan Y4 sebesar 0,097. Dari hasil konvergen validity di atas, masih ada nilai loading yang $<0.6$ yaitu X1.1, $\mathrm{X} 1.2, \mathrm{X} 1.3, \mathrm{X} 1.5, \mathrm{X} 2.1, \mathrm{Y} 3$, dan Y4, sehingga indikatorindikator tersebut dinyatakan tidak valid maka dikeluarkan dari model. Sedangkan indikator dengan nilai loading $>0.6$ dikatakan valid, maka indikator tersebut valid sebagai pengukur konstruknya. Berdasarkan pada nilai loading yang valid untuk setiap indikator maka dilakukan uji algoritma kedua untuk melihat validitas indikator sebagai pengukur konstruknya. Adapun hasil uji algoritma kedua diperlihatkan pada gambar dibawah ini :

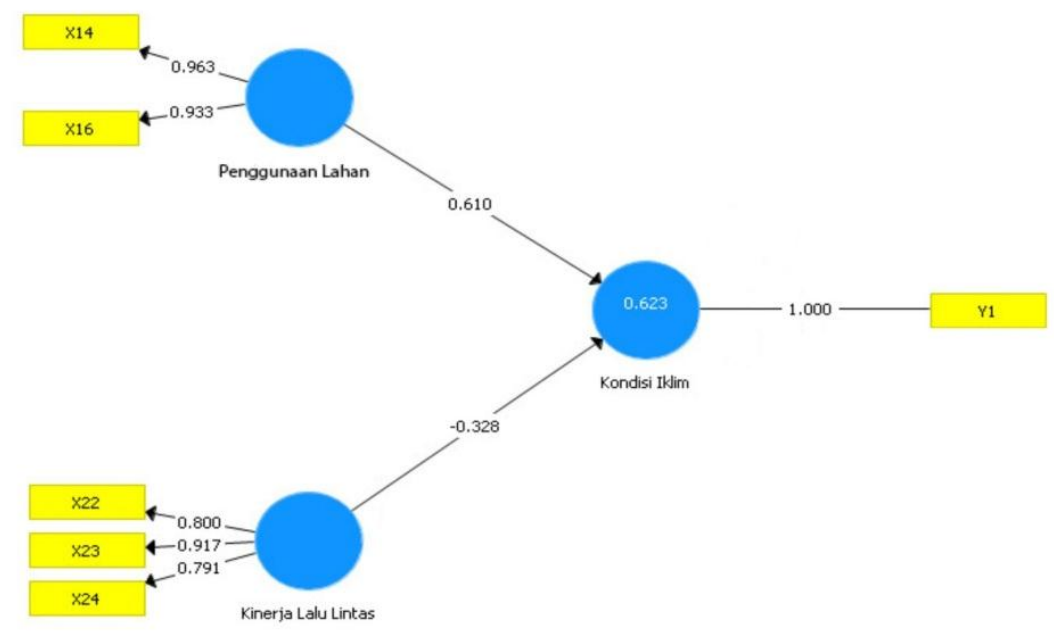

Gambar 5. Model PLS Algoritma 2

Berdasarkan gambar 5 diatas, menunjukkan bahwa pada diagram jalur model PLS Algoritma 2 sudah tidak terdapat varian yang negatif, sehingga indikator yang ada dinyatakan valid dengan jumlah indikator 7. Adapun nilai loading factor untuk setiap indikator diatas diperlihatkan pada tabel dibawah ini :

Tabel 6. Nilai Loading Factor Indikator Algoritma 2

\begin{tabular}{lccc}
\hline & $\begin{array}{c}\text { Kinerja Lalu } \\
\text { Lintas }\end{array}$ & $\begin{array}{c}\text { Kondisi } \\
\text { Iklim }\end{array}$ & $\begin{array}{c}\text { Penggunaan } \\
\text { Lahan }\end{array}$ \\
\hline X1.4 & & & 0,963 \\
X1.6 & & & 0,933 \\
X2.2 & 0,800 & & \\
X2.3 & 0,917 & & \\
X2.4 & 0,791 & & \\
Y1 & & 1,000 & \\
\hline
\end{tabular}

Pada Tabel 6 di atas menunjukkan bahwa semua indikator memperoleh nilai loading diatas 0,6 dimana nilai loading > 0.6 dikatakan valid (Igbaria dkk. dalam Wijanto,
2008:65 dan Ghozali, 2008a:135). Oleh karena itu semua indikator tersebut dinyatakan valid sebagai pengukur konstruknya. Berdasarkan hasil analisis ditunjukkan bahwa variabel manifest (indikator) yang menentukan dalam model ini hanya ada 6 . Untuk variabel penggunaan lahan ditentukan oleh indikator penggunaan lahan rumput dan tubuh air. Untuk variabel kinerja lalu lintas ditentukan oleh indikator jumlah hambatan samping, volume kendaraan, dan kepadatan rata-rata. Sementara untuk kondisi iklim ditentukan oleh indikator suhu udara.

\subsection{Hasil Uji Model Struktural}

Untuk menguji model struktural dilakukan dengan melihat nilai R2 yang merupakan uji Squared Multiple Correlation. Koefisien korelasi berganda yang dikuadratkan ( squared multiple correlation coefficient $=$ R2) digunakan untuk mengetahui seberapa besar varian variabel laten menjelaskan variabel indikator. Berdasarkan hasil analisis diperolah konstruk kondisi iklim memperoleh nilai R2 
sebesar 0,623 yang dapat diinterpretasikan bahwa varian pada kondisi iklim dapat dijelaskan oleh konstruk penggunaan lahan dan kinerja lalu lintas sebesar $62,3 \%$ sedangkan sisanya $37,7 \%(100 \%-62,3 \%)$ dijelaskan oleh variabel lain diluar yang diteliti.. Hasil nilai R-square selengkapnya disajikan pada tabel di bawah ini.

Tabel 7. Nilai R-Square untuk Uji Goodness of The Fit

\begin{tabular}{lc}
\hline & R Square \\
\hline Kondisi Iklim & 0,623 \\
\hline
\end{tabular}

Berdasarkan pada nila R-Square diatas tingkat kepercayaan hubungan atau pengaruh variabel independen (variabel indikator) yaitu pengunaan lahan dan kinerja lalu lintas terhadap variabel dependen (variabel laten) kondisi iklim $62,3 \%$. Hal ini menunjukkan bahwa terdapat variabel independen (variabel indikator) lainnya yang tidak diteliti dalam penelitian ini namun memiliki hubungan dan pengaruh terhadap variabel dependen (variabel laten). Namun tingkat kepercayaan hubungan variabel independen yang digunakan dalam penelitian ini sudah lebih besar dari variabel independen yang tidak digunakan, sehingga variabel independen yang digunakan dapat digunakan sebagai pengukut variabel dependen.

Selanjutnya untuk Uji hipotesis dimaksudkan untuk melihat signifikansi pengaruh antar konstruk independen terhadap dependen dan menjawab apa yang telah dihipotesiskan. Pengujian dengan taraf signifikansi 5\% jika nilai t-statistic > 1,96 maka hipotesis nol (H0) ditolak. Nilai $\mathrm{t}$-statistik koefisien pengaruh dari konstruk laten diperoleh dari PLS Bootstrapping. Hasil Model PLS Bootstrapping disajikan pada gambar di bawah ini.

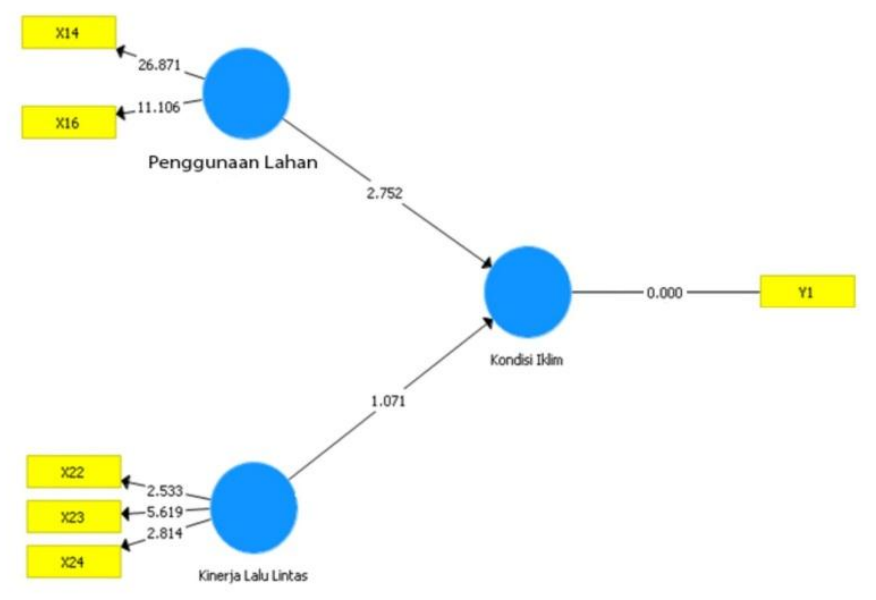

\section{Gambar 6. Model PLS Bootstrapping}

Nilai koefisien parameter dapat dilihat pada nilai (original sample) dan nilai signifikansi t-statistik hasil pengolahan PLS Bootstrapping dapat dilihat pada tabel di bawah ini.

Tabel 8. Nilai Koefisien (Original Sample), Standard Error dan T-Statistics

\begin{tabular}{lcccc}
\hline & $\begin{array}{c}\text { Original } \\
\text { Sample }(\mathbf{O})\end{array}$ & $\begin{array}{c}\text { Standard } \\
\text { Deviation } \\
\text { (STDEV) }\end{array}$ & $\begin{array}{c}\text { T Statistics } \\
(\mid \mathbf{O} / \text { STDEV } \mid)\end{array}$ & P Values \\
\hline Kinerja Lalu Lintas -> Kondisi Iklim & $-0,328$ & 0,306 & 1,071 & 0,285 \\
Penggunaan Lahan -> Kondisi Iklim & 0,610 & 0,222 & 2,752 & 0,006 \\
\hline
\end{tabular}

Tabel 8 diatas dijadikan sebagai acuan utama untuk melakukan uji hipotesis. Kriteria pengujian adalah tolak H0 jika nilai T-Statistics $>1,96$ atau nilai $\mathrm{P}<0,05$. Pada pengujian hipotesis pengaruh penggunaan lahan terhadap kondisi iklim menunjukkan hasil nilai T-Statistik sebesar $2,752>1,96$ atau nilai $\mathrm{P}$ sebesar $0,040<0,05$ (lihat tabel 8 ) maka H0 ditolak, yang berarti penggunaan lahan berpengaruh terhadap kondisi iklim.Sementara pengujian hipotesis pengaruh kinerja lalu lintas terhadap kondisi iklim menunjukkan hasil nilai T-Statistik sebesar 1,071 < 1,96 atau nilai $\mathrm{P}$ sebesar 0,285 > 0,05 (lihat tabel 16) maka H0 diterima, yang berarti kinerja lalu lintas tidak berpengaruh terhadap kondisi iklim.

Hasil penelitian ini menunjukkan bahwa penggunaan lahan berpengaruh signifikan terhadap kondisi iklim. Hasil ini menunjukkan bahwa penggunaan lahan di koridor ruas jalan Hertasning-Tun Abdul Razak dapat menyebabkan meningkatnya atau menurunnya kondisi iklim dalam hal ini direpresentasikan oleh suhu udara di kawasan tersebut. Penggunaan lahan berkaitan dengan kegiatan manusia pada bidang lahan tertentu, misalnya permukiman, perkotaan dan persawahan. Penggunaan lahan juga merupakan pemanfaatan lahan dan lingkungan alam untuk memenuhi kebutuhan manusia dalam penyelenggaraan kehidupannya. Pertumbuhan penduduk diperkotaan yang begitu cepat, serta aktivitas pembangunan dalam berbagai bidang akan menyebabkan meningkatnya permintaan lahan. Hal inilah yang akan mendorong terjadinya alih fungsi lahan pertanian ke non pertanian pada kawasan perkotaan. Fenomena ini terjadi juga pada koridor ruas jalan Hertasning-Tun Abdul Razak, dimana pada koridor ini dulunya didominasi oleh penggunaan lahan berupa sawah dan rumput, namun saat ini mengarah penggunaan lahan berupa pemukiman dan kegiatan perdagangan dan jasa. 
Pada akhirnya akan meningkatkan daerah terbangun (Sakti, 2016).

Hasil penelitian ini menunjukkan hasil yang sedikit berbeda dengan penjelasan sebelumnya. Dimana kecenderungannya suhu pada area yang kepadatan bangunannya tinggi yaitu pada daerah Hertasning lebih rendah dibandingkan suhu pada daerah Tun-Abdul Razak yang kepadatan bangunannya lebih rendah. Hal ini dikarenakan penutupan pohon pada ruas jalan Hertasning lebih padat dibandingkan pada daerah Tun-Abdul Razak, meski pada daerah ruas jalan Hertasning bangunan lebih padat namun telah tertata dengan lebih baik. Penataan kota yang lebih baik dengan penempatan pohon pelindung mempengaruhi pelepasan dan penyimpanan panas pada kawasan perkotaan (Coutts et al., 2007).

\section{Kondisi Iklim}

a) Pengaruh Kinerja Lalu Lintas Terhadap

Hasil penelitian ini menunjukkan bahwa kinerja lalu lintas tidak berpengaruh signifikan terhadap kondisi iklim. Hal ini menunjukkan bahwa peningkatan dan penurunan kinerja lalu lintas pada koridor ruas jalan Hertasning-Tun Abdul Razak tidak akan meningkatkan atau menurunkan kondisi iklim dalam hal ini suhu udara di kawasan tersebut. Hasil ini sedikit berbeda dengan berbagai literatur yang menjelaskan bahwa kepadatan kendaraan sebagai bagian dari indikator kinerja lalu lintas dapat mempengaruhi iklim. Penggunaan bahan bakar bensin dan solar pada kendaraan berdampak global pada kualitas udara, kesehatan manusia, dan perubahan iklim (Huang et al., 2020). Sektor transportasi berkontribusi utama pada peningkatan emisi gas rumah kaca yang dapat menyebabkan terjadinya perubahan iklim dalam skala makro. Perbedaan hasil penelitian ini dengan berbagai hasil penelitian sebelumnya dikarenakan adanya perbedaan skala pengukuran. Penelitian ini dilakukan pada skala mikro lingkungan perkotaan, sehingga iklim yang diukur adalah iklim mikro. Pada skala mikro sektor transportasi tidak berkontribusi langsung terhadap peningkatan iklim mikro, namun berpengaruh terhadap iklim makro melalui fenomena gas rumah kaca. Pengurangan emisi transportasi memainkan peran penting dalam mencapai tujuan 1,5 ${ }^{\circ} \mathrm{C}$ dari Perjanjian Paris (Masson-delmotte, n.d., 2018).

\section{Kesimpulan dan Saran}

Hasil penelitian dapat disimpulkan bahwa penggunaan lahan berpengaruh signifikan terhadap kondisi iklim pada koridor ruas jalan Hertasning-Tun Abdul Razak. Kesimpulan tersebut berdasarkan nilai T-Statistik sebesar $2,752>1,96$ atau nilai $\mathrm{P}$ sebesar $0,040<0,05$ (lihat tabel 16). Artinya kondisi iklim di koridor ruas jalan HertasningTun Abdul Razak dipengaruhi oleh penggunaan lahan. Kinerja lalu lintas tidak berpengaruh signifikan terhadap kondisi iklim pada koridor ruas jalan Hertasning-Tun Abdul Razak. Kesimpulan tersebut berdasarkan nilai TStatistik sebesar 1,071 < 1,96 atau nilai $\mathrm{P}$ sebesar 0,285 > 0,05 (lihat tabel 16). Artinya kondisi iklim di koridor ruas jalan Hertasning-Tun Abdul Razak tidak dipengaruhi oleh kinerja lalu lintas.

\section{Daftar Pustaka}

Buraerah, M. F., Rasyidi, E. S., \& Sandi, R. (2020). Pemetaan Perubahan Penggunaan Lahan Di Wilayah Kabupaten Takalar Tahun 1999-2019 Menggunakan Sistem Informasi Geografis. Ecosystem, 20(1).

Cahyani Mokoginta, R., Syafri, S., \& Jufriadi, J. (2021). Alih Fungsi Lahan Pertanian Di Kawasan Jalan Hertasning Baru Kelurahan Kassi-Kassi Kota Makassar. Journal of Urban Planning Studies, 1(2), 204-214. https://doi.org/10.35965/jups.v1i2.65

Coutts, A. M., Beringer, J., \& Tapper, N. J. (2007). Impact of increasing urban density on local climate: Spatial and temporal variations in the surface energy balance in Melbourne, Australia. Journal of Applied Meteorology and Climatology, 46(4),

$477-493$ https://doi.org/10.1175/JAM2462.1.

Centers for Disease Control and Prevention (CDC). 1997. Vectors of Lymphatic Filariasis. www.cdc.gov/.../mosquitoes_lymphatic_filar.htm.. 8 September 2020.

Dahlan. 2011. Potensi hutan kota sebagai alternatif substitusi fungsi alat pendingin ruangan (air conditioner) (Studi kasus di Kampus IPB Darmaga). Skripsi. Departemen Konservasi Sumberdaya Hutan dan Ekowisata, Fakultas Kehutanan, IPB, Bogor.

Departemen Pekerjaan Umum., 1997, Manual Kapasitas Jalan Indonesia (MKJI), Direktorat Jenderal Bina Marga dan Departemen Pekerjaan Umum Jakarta.

Rasyidi, E. S., Sandi, R., \& Buraerah, M. F. (2020). Monitoring Perubahan Suhu Ibu Kota Negara Tahun 1993-2019 Menggunakan Citra Satelit Landsat (Studi Kasus: Jakarta, Singapura, Kuala Lumpur Dan Bangkok). Ecosystem, 20(1), 50-58.

Environmental Protection Agency. (2009). Retrieved February 14, 2011, from Urban Heat Island Effect: http://www.epa.gov/heatisld/about/index .htm.

Ghozali, Imam, 2008a, Model Persamaan Struktural, Konsep dan Aplikasi dengan Program AMOS 16.0, Badan Penerbit Universitas Diponegoro, Semarang.

Ghozali, Imam, 2006, Aplikasi Analisis Multivariate dengan Program SPSS, Badan Penerbit Universitas Diponegoro, Semarang.

Haryono, S., dan Wardoyo, P. (2012). Structural Equation Modeling, Bandung, PT. Intermedia Personalia Utama.

Huang, Y., Unger, N., Harper, K., \& Heyes, C. (2020). Global Climate and Human Health Effects of the Gasoline and Diesel Vehicle Fleets. GeoHealth, 4(3), $1-13$. https://doi.org/10.1029/2019GH000240.

IPCC. 2018. Summary for Policymakers. In: MassonDelmotte V, Zhai P, Pörtner H-O, Roberts D, Skea J, Shukla PR, Pirani A, Moufouma-Okia W, Péan C, Pidcock R, Connors S, Matthews JBR, Chen Y, Zhou X, Gomis MI, Lonnoy E, Maycock T, Tignor $\mathrm{M}$, Waterfield $\mathrm{T}$, editors. Global Warming of 
$1.5^{\circ} \mathrm{C}$. An IPCC Special Report on the impacts of global warming of $1.5^{\circ} \mathrm{C}$ above pre-industrial levels and related global greenhouse gas emission pathways, in the context of strengthening the global response to the threat of climate change, sustainable development, and efforts to eradicate poverty. In Press.

Maru, R., \& Ahmad, S. (2015). The relationship between land use changes and the urban heat Island phenomenon in Jakarta, Indonesia. Advanced Science Letters, 21(2), 150-152. https://doi.org/10.1166/asl.2015.5842.

McGee, T.G. 1997. The Emergence of Desa-Kota Regions in Asia: Expanding a Hypothesis. In The Extended Metropolis and Settlement Transsition in Asia. The University of Hawaii Press. Honolulu.

MI, Taking. (2015). Perubahan Pemanfaatan Lahan dan Implikasinya dalam Pengendaliaan Ruang di Kawasan Perkotaan Sungguminasa. Universitas Bosowa.

Muhammad Afandi Naser, M. ., Manaf, M., \& Budiharto, T. (2021). Pengendalian Pemanfaatan Ruang Kawasan Terdampak Banjir Di Perkotaan Sinjai. Journal of Urban Planning Studies, 1(2), $147-164$.

Rahman, Musdalifah. 2016. Pengaruh Aktifitas Perdagangan Dan Jasa Terhadap Volume Lalu Lintas di Ruas Jalan Hertasning Raya, Kota Makassar. Jurusan Teknik Perencanaan Wilayah dan Kota, UIN Alauddin Makassar.

Rushayati, S. B., Prasetyo, L. B., Puspaningsih, N., \& Rachmawati, E. (2016). Adaptation Strategy Toward Urban Heat Island at Tropical Urban Area. Procedia Environmental Sciences, 33(in 1997), 221-229.

Sakti, H.H. (2016). Fenomena Perubahan Pemanfaatan Ruang dan Pertumbuhan Aktivitas Perkotaan (Kasus Koridor Ruas Jalan Hertasning-Samata Makassar-Gowa). Jurnal Plano Madani. Vol. 5 No.2. Hlm : 171-179.

Sandi, R., Rasyidi, E. S., \& Fikruddin, M. (2020). Landslide Of Karalloe Dam Site Gowa Regency, South Sulawesi Province. Ecosystem, 20(1), 3440.

Santamouris, M. (2013). Using cool pavements as a mitigation strategy to fight urban heat. 26, 224240.

Surya, B., Hamsina, H., Ridwan, R., Baharuddin, B., Menne, F., Fitriyah, A. T., \& Rasyidi, E. S. (2020). The Complexity of Space Utilization and Environmental Pollution Control in the Main Corridor of Makassar City, South Sulawesi, Indonesia. Sustainability, 12(21), 9244.

UNEP. (2003). United Nations Environmental Programme. Retrieved February 14, 2011, from How will global warming affect my world: http://www.unep.org/dec/docs/ipcc_wgii _guideE.pdf J@TI.

Weng, Q., Lu, D., \& Schubring, J. (2004). Estimation of land surface temperature-vegetation abundance relationship for urban heat island studies. Remote Sensing of Environment, 89(4), 467-483.
Wijanto, Setyo Hari, 2008, Structural Equation Modeling dengan Lisrel, Konsep dan Tutorial, Graha Ilmu, Jakarta.

Hanif Zahran, M., Salim, A., \& Budiharto, T. (2021). Arahan Mitigasi Bencana Kawasan Rawan Longsor Di Kabupaten Sinjai. Journal of Urban Planning Studies, 1(2), 196-203. 